\title{
Camellia tuyenquangensis (Theaceae), a new species from Vietnam
}

\author{
Ninh Nguyet Hai Le, Chiyomi Uematsu ${ }^{1}$, Hironori Katayama ${ }^{2}$, Lieu Thi Nguyen ${ }^{1}$, Ninh Tran $^{3}$, \\ Dung Van Luong ${ }^{4}$ and Son Thanh Hoang ${ }^{5 *}$ \\ Department of Biology, Hoa Lu University, Ninh Binh 43000, Vietnam \\ ${ }^{1}$ Graduate School of Science, Botanical Gardens of Osaka City University, Osaka 5420072, Japan \\ ${ }^{2}$ Food Resources Research and Education Center, Graduate School of Agricultural Science, Kobe University, Kobe 6520000, Japan \\ ${ }^{3}$ Faculty of Biology, VNU University of Science, Hanoi 100000, Vietnam \\ ${ }^{4}$ Deparment of Biology, Da Lat University, Dalat 670000, Vietnam \\ ${ }^{5}$ Silviculture Research Institute, Hanoi 100000, Vietnam
}

(Received 22 February 2017; Revised 14 June 2017; Accepted 19 June 2017)

\begin{abstract}
Camellia tuyenquangensis (Theaceae), a new yellow species of camellia from the Chiem Hoa district of the Tuyen Quang province in Vietnam, is described and illustrated. Camellia tuyenquangensis is similar to Camellia luongii but different from the latter species in several morphological features: leaves oblong-ovate to narrow elliptic; flowers 1-2; bracteoles glabrous on both sides; sepal margins ciliate; style cleft one half of the length. The morphological data provisionally support its placement in Camellia sect. Chrysantha Chang.
\end{abstract}

Keywords: Camellia, new species, Theaceae, Vietnam

Vietnam is located on the Indochina peninsula in Southeast Asia. It has a tropical monsoon climate, with humidity averaging at 84 percent throughout the year. Three quarters of Vietnam's territory are made up of low mountains and hilly regions. Therefore, the natural conditions of Vietnam have been identified as favorable for Camellia species. The wild Camellia were discovered in many parts of Vietnam's territory, stretching from north to south. The colors of their flowers are white, pink, red, and yellow. Of them, the yellow Camellia are rare and have the considerable economic potential for its colorful beauty.

In the world, the number of species in Camellia genus was estimated to be from 120 to 300 (Sealy, 1958; Chang and Bartholomew 1984; Ming and Bartholomew 2007) and this genus is the largest genus of the Theaceae. Recently, many additional new species of Camellia have been discovered and described from Vietnam (Ninh et al., 2012; Orel et al., 2012, 2014; Ninh and Dung, 2013; Orel and Curry 2014; Ninh and Ninh, 2015; Luong et al., 2016).

A total number of Vietnamese yellow Camellia species recorded until now is about 40 species (Ninh and Dung, 2016).
Mostly, the yellow Camellia of Vietnam are rare and highly endemic, however, they are not so many in individual numbers and narrowly distributed. Many yellow Camellia species in northern Vietnam are being exploited to eradicate in the wild.

Based on several our surveys in the last two years, many yellow Camellia samples were obtained in the north Vietnam. Among them, a number of individuals recorded from Chiem Hoa district, Tuyen Quang province are distinctive. After analyzing and comparing the morphological characteristics with close species, we assert that it is a new species, named as Camellia tuyenquangensis.

\section{Taxonomic Treatment}

Camellia tuyenquangensis D. V. Luong, N. N. H. Le \& N. Tran, sp. nov. (Figs. 1, 2).

TYPE: VIETNAM. Tuyen Quang province: Chiem Hoa district, 25 Oct 2016 (fl), Luong Van Dung 161101 (holotype, DLU; isotype, SING).

Shrub, 5-6 $\mathrm{m}$ tall; young branches light brown, glabrous;

\footnotetext{
*Author for correspondence: hoangsonfsiv@gmail.com
} 


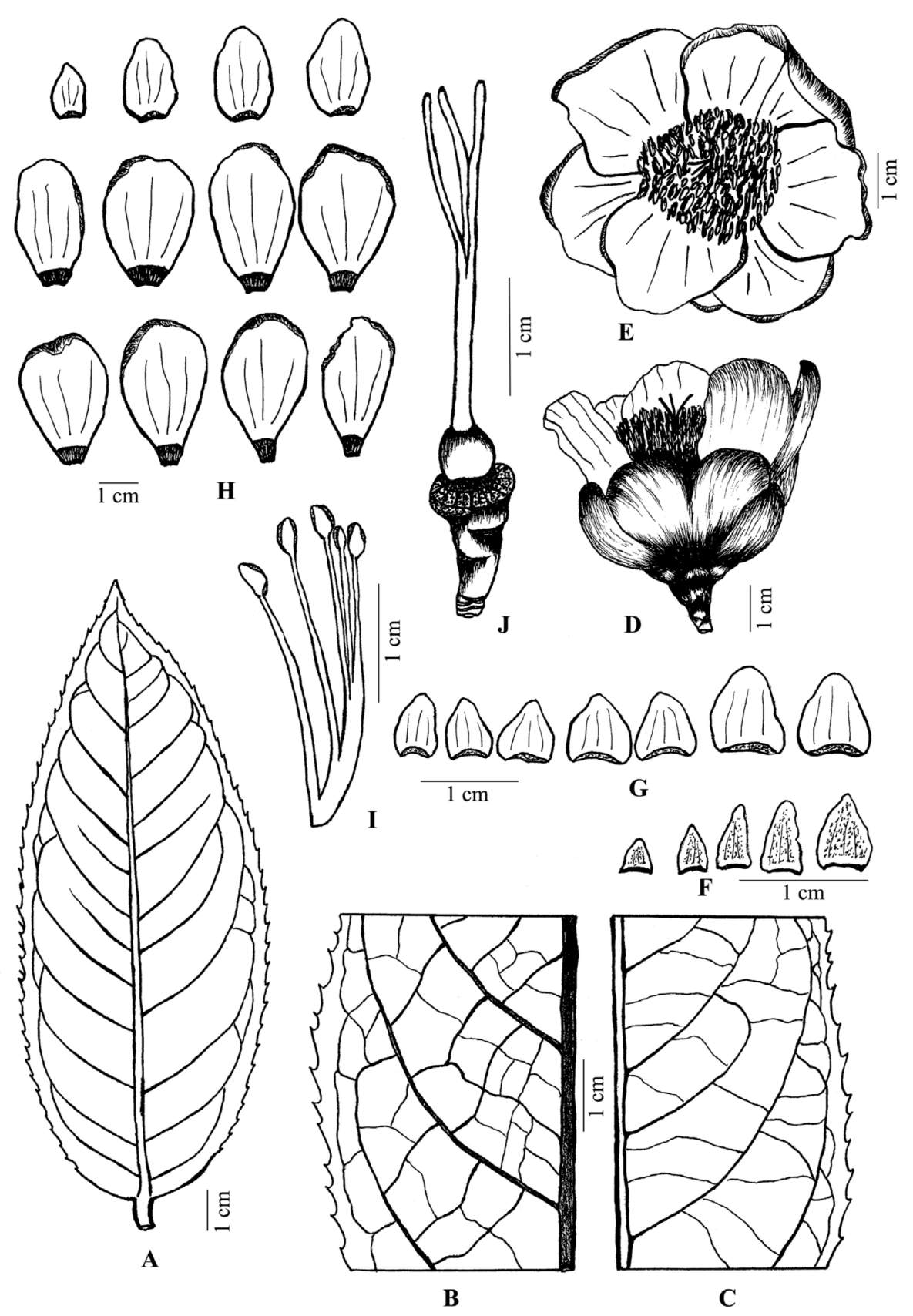

Fig. 1. Camellia tuyenquangensis D. V. Luong, N. N. H. Le \& N. Tran. A. Leaf, adaxial view. B. Venation detail of leaf (abaxial surface). C. Venation of leaf (adaxial surface). D. Flower, side view with some petals removed. E. Flower, top view. F. Bracteoles (inner surfaces shown). G. Sepals (inner surfaces). H. Petals (inner surfaces), outer whorl in top row, followed by middle and inner whorls. I. Stamens. J. Pedicel and gynoecium (other floral parts removed). Drawn by Dung Van Luong.

old branches white-grey. Leaves simple, alternate; petioles 10$15 \mathrm{~mm}$ long, glabrous; blades thick and coriaceous, oblongovate to narrow elliptic, $14-18 \mathrm{~cm}$ long, 5-8 cm wide, apex acute or acuminate, bases rounded, margins serrate and sometime serrulate at the upper part, adaxial surface green, glabrous and not shinning, abaxial surface yellowish green and glabrous, lateral veins 9-11 pairs, sunken adaxially, protruding abaxially. Flowers 1 or 2, terminal or axillary, $5.5-6.0 \mathrm{~cm}$ in diam.; pedicels $10 \mathrm{~mm}$ long, glabrous. Bracteoles 4-5, broadly triangular, overlapping, margins ciliate, glabrous on both sides, 3-6 mm long and 2.5-4 mm wide. Sepals 7, spiral, broadly triangular or elliptic, $7-11 \mathrm{~mm}$ long and $4.5-9 \mathrm{~mm}$ wide, margins ciliate, glabrous on both sides. Petals 12, yellow, arranged in 3 whorls; the outer whorl 4, elliptic, 17-30 mm 

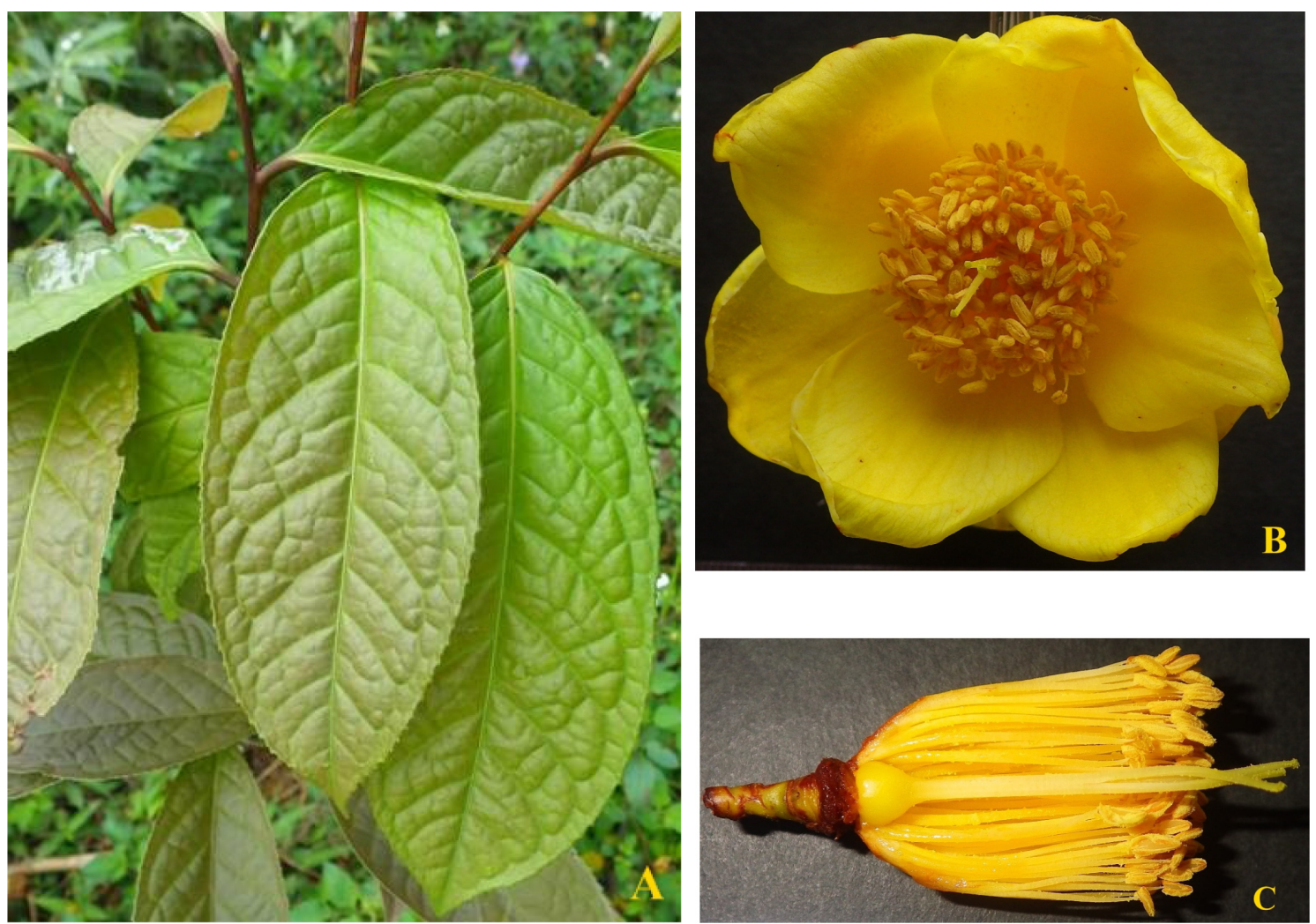

Fig. 2. Camellia tuyenquangensis D. V. Luong, N. N. H. Le \& N. Tran. A. Leafy branch. B. Flower, top view. C. Pedicel, part of androecium and gynoecium revealed after removing other floral parts (Photos: Dung Van Luong).

long, 13-20 mm wide, the middle whorl 4, elliptic, obovate, 38-45 mm long, 23-33 mm wide, the inner whorl 4, basally connate for 5-6 mm, obovate, elliptic, $42-45 \mathrm{~cm}, 24-30 \mathrm{~mm}$ wide, glabrous on both sides. Stamens 250 , in $4-5$ whorls, outer whorl connate for $10-14 \mathrm{~mm}$ at the base, adnate to petal bases, anthers yellow, 2-2.5 mm; filaments glabrous, 25$30 \mathrm{~mm}$ long. Ovaries 3-locular, ovoid, $5 \mathrm{~mm}$ long, $5 \mathrm{~mm}$ wide, glabrous; styles $30 \mathrm{~mm}$ long, 3-cleft to middle or 3-cleft half the length of style. Fruit not seen.

Etymology: The specific epithet of the new species refers to the location of discovery, Tuyen Quang province, Vietnam.

Distribution and phenology: This species was found in the forest of Chiem Hoa district, Tuyen Quang province, at the elevations of 500-800 m. It was collected with the flowers in October. No mature capsules or seeds were evident. It grows mixed with other species such as: Caryodaphnopsis tonkinensis, Litsea dilleniifolia, Fernandoa collignonii, Bursera tonkinensis, Diospyros mollis, and Phoebe macrocrpa, etc.

\section{IUCN Red List category}

The Area of Occupancy (AOO) for C. tuyenquangensis is estimated to be less than $1 \mathrm{~km}^{2}$. Despite a thorough survey of the area around the type locality, only eight additional mature trees were found. The total known population of the species is consisted of fewer than 50 indivuduals, and it would be qualified as Critically Endangered (CR) under criterion D (IUCN, 2011).

Notes: This is one of very few yellow Camellia species in the world that have a gynoecium with cleft styles. This is known in just five other species, including Camellia capitata Orel, Curry and Luu, C. luteopallida Luong, Nguyen and Luu, C. oconoriana Orel, Curry and Luu, C. pubipetala Wan and Huang and $C$. luongii Tran and Le. Comparison of these species with $C$. tuyenquangensis is shown in Table 1.

Camellia tuyenquangensis is most similar to C. luongii, but different from those characters as leaves oblong-ovate to narrow elliptic; flowers 1-2; bracteoles glabrous on both sides; sepals margins ciliate; style cleft $1 / 2$ the length.

In having yellow flowers with a 3-carpellate ovary, $C$. tuyenquangensis generally resembles many other yellow Camellia species that are placed in sections Archecamellia, Bidoupia, Capitata, Chrysantha, Corallinae, Obovoidea, Piquetia, and Thea. However, Camellia tuyenquangensis 
Table 1. Morphological comparison of Camellia tuyenquangensis with C. capitata, C. Luteopallida, C. pubipetala and C. luongii (data partly based on Luong et al. 2016, Ninh and Ninh 2015, Orel et al. 2014, Chang and Bartholomew 1984).

\begin{tabular}{|c|c|c|c|c|c|}
\hline Characters & C. tuyenquangensis & C. capitata & C. luteopallida & C. pubipetala & C.luongii \\
\hline Young branches, hairiness & Glabrous & Pubescent & Glabrous & Densely hirsute & Glabrous \\
\hline Leaf blade, shape & $\begin{array}{l}\text { Narrow-ovate, } \\
\text { sometimes elliptic }\end{array}$ & $\begin{array}{l}\text { Elliptic to ovate, } \\
\text { sometimes obovate }\end{array}$ & Elliptic to ovate & Elliptic & $\begin{array}{l}\text { Broad elliptic, } \\
\text { elliptic to narrow elliptic }\end{array}$ \\
\hline Leaf apex, shape & Acute or acuminate & $\begin{array}{l}\text { Cuspidate, } \\
\text { acute on smaller leaves }\end{array}$ & Cuspidate or acuminate & $\begin{array}{c}\text { Caudate, } \\
\text { rarely abruptly acuminate, } \\
\text { apiculate }\end{array}$ & Acuminate \\
\hline Leaf base, shape & Rounded & $\begin{array}{l}\text { Obtuse, subcordate, } \\
\text { acute in less developed leaves }\end{array}$ & Obtuse or cuneate & Rounded to cuneate & Rounded to cuneate \\
\hline Leaf blade, hairiness & Glabrous both sides & $\begin{array}{l}\text { Glabrous above, } \\
\text { finely and sparsely hairy below }\end{array}$ & Glabrous both sides & $\begin{array}{c}\text { Glabrous above, } \\
\text { densely villous below }\end{array}$ & Glabrous both sides \\
\hline Petiole, hairiness & Glabrous & Finely white hairy & Glabrous & Densely hirsute & Glabrous \\
\hline $\begin{array}{l}\text { Flowers, number and } \\
\text { position }\end{array}$ & $1-2$, terminal or axillary & Clusters of 9-12(-14), terminal & 1 or rarely 2 , terminal & 1 , seldom 2 , terminal or axillary & 1 , terminal or axillary \\
\hline Pedicel, length & $10 \mathrm{~mm}$ & (sessile) & (subsessile) & (subsessile) & $15 \mathrm{~mm}$ \\
\hline $\begin{array}{l}\text { Bracteoles and sepals, } \\
\text { hairiness }\end{array}$ & $\begin{array}{l}\text { Glabrous on both sides, } \\
\text { margins ciliate }\end{array}$ & $\begin{array}{l}\text { Finely tomentose, } \\
\text { also hairy on margins }\end{array}$ & Hairy on both sides & $\begin{array}{l}\text { Outer surfaces puberulent, } \\
\text { margins short ciliate }\end{array}$ & $\begin{array}{c}\text { Outer surface glabrous; white, } \\
\text { minutely and scattered ciliolate; } \\
\text { inner surface with finely white } \\
\text { puberulous, } \\
\text { sometime glabrous }\end{array}$ \\
\hline Petals, hairiness & $\begin{array}{l}\text { Glabrous on both sides, } \\
\text { margins hairless }\end{array}$ & Glabrous on both sides & $\begin{array}{l}\text { Dense appressed brown hairs } \\
\text { on both sides }\end{array}$ & Outside puberulent & Glabrous on both sides \\
\hline Filaments, hairiness & Glabrous & Glabrous & Sparsely hairy at base & Puberulent & Glabrous \\
\hline $\begin{array}{l}\text { Ovary, hairiness, locules } \\
\text { and shape }\end{array}$ & Glabrous, 3-locular, ovoid & $\begin{array}{l}\text { Glabrous, 3-locular; } \\
\text { roughly triangular, ridged }\end{array}$ & $\begin{array}{l}\text { Glabrous, 3-locular, } \\
\text { ovoid, 3-lobed }\end{array}$ & $\begin{array}{l}\text { Densely puberulent, } \\
\text { 3-4-locular, subglobose }\end{array}$ & $\begin{array}{l}\text { Glabrous, } \\
\text { 3-locular, ovoid }\end{array}$ \\
\hline $\begin{array}{l}\text { Style, hairiness, extent to } \\
\text { which cleft }\end{array}$ & $\begin{array}{l}\text { Glabrous, } 3 \text {-cleft, } \\
\text { clefts c. } 1 / 2 \text { style length }\end{array}$ & $\begin{array}{l}\text { Glabrous, } 3 \text {-cleft, } \\
\text { clefts c. } 4 / 5 \text { style length }\end{array}$ & $\begin{array}{l}\text { Dense white appressed hairs, } \\
\text { 3-cleft, clefts c. } 4 / 5 \text { style length }\end{array}$ & $\begin{array}{l}\text { Puberulent, } 3-4 \text {-cleft, } \\
\text { clefts c. } 1 / 3 \text { style length }\end{array}$ & $\begin{array}{l}\text { Glabrous, } 3 \text {, } \\
\text { free to the base }\end{array}$ \\
\hline
\end{tabular}


shares most morphological characteristics with Camellia section Chrysantha Chang (Chang and Bartholomew, 1984), including medium to large yellow pedicellate flowers, 5 bracts, 7 persistent sepals, 12 petals, stamens in 4 whorls with basally connate filaments in the outer whorl and free filaments in the inner whorls, a 3-locular glabrous ovary, and styles cleft into 3 parts. The flowers of Camellia tuyenquangensis differ from other species in section Chrysantha only in having both axillary and terminal (not strictly axillary) flowers and 4-5 (not 5-7) bracteoles.

\section{Acknowledgments}

The authors would like to express their sincere thanks to Mr. Le Cong Doan, Mr. Lau Quoc Thuong, and Mr. Nguyen Ngoc Cuong who provided valuable information leading to the discovery of this species; also to Ms. Le Thi Phuong Hong, Dr. Soo-Yong Kim and Dr. Khoon Meng Wong for helpful suggestions as well as language assistance at various stages of the manuscript. We are also grateful for the support provided through the JSPS KAKENHI Grant Number JP16K07239, Japan.

\section{Literature Cited}

Chang, H. T and B. Bartholomew. 1984. Camellias. B.T. Bastford Ltd., London, $211 \mathrm{pp}$.

IUCN. 2011. International union for conservation of nature, red list categories and criteria, ver. 3.1. Rerieved Mar. 2, 2011, available from http://www.iucnredlist.org.

Luong, V. D., H. T. Luu, T. Q. T. Nguyen and Q. D. Nguyen. 2016.
Camellia luteopallida (Theaceae), a new species from Vietnam. Annales Botanici Fennici 53: 135-138.

Ming, T. L. and B. Bartholomew. 2007. Theaceae. In Flora of China. Vol. 12. Hippocastanaceae through Theaceae. Wu, Z.Y. and P. H. Raven. (eds.), Science Press, Beijing and Missouri Botanical Garden Press, St. Louis, MO. Pp. 366-478.

Ninh, L. N. H and L. V. Dung. 2016. General information about the Yellow Camellia species in Vietnam. In Proceedings of Dali International Camellia Congress. International Camellia Society, Dali, Yunnan, China.

Ninh, T., N. Hakoda and L. V. Dung. 2012. A new species of yellow Camellia (sect. Piquetia) from Vietnam. International Camellia Journal 44: 161-162.

Ninh, T. and L. V. Dung. 2013. Camellia dilinhensis: A new yellow species from Vietnam. International Camellia Journal 45: $87-89$.

Ninh, T. and L. N. H. Ninh. 2015. A new yellow Camellia species from North of Vietnam. International Camellia Journal 47: 3639.

Orel, G., P. G. Wilson, A. S. Curry and L. H. Truong. 2012. Camellia inusitata (Theaceae), a new species forming a new section (Bidoupia) from Vietnam. Edinburgh Journal of Botany 69: 347-355.

Orel, G. and A. S. Curry. 2014. A new species of Camellia section Dalatia (Theaceae) from Vietnam. Telopea 17: 99-105.

Orel, G., P. G. Wilson, A. S. Curry and L. H. Truong. 2014. Four new species and two new sections of Camellia (Theaceae) from Vietnam. Novon 23: 307-318.

Sealy, J. R. 1958. A Revision of the Genus Camellia. Royal Horticulture Society, London, 239 pp. 